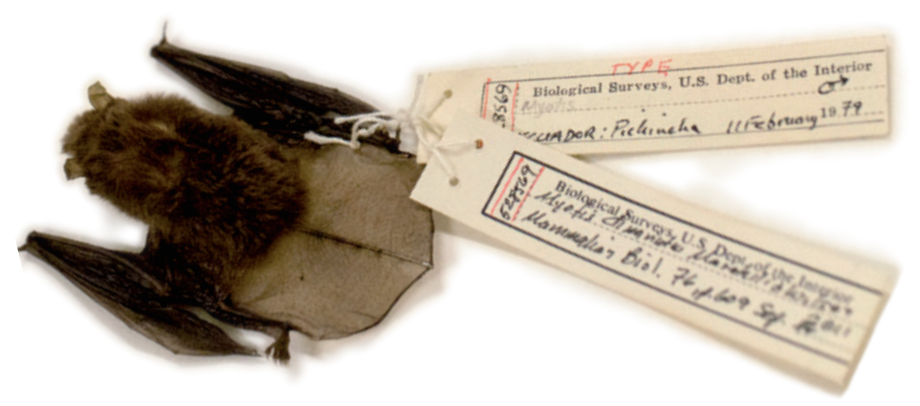

\title{
The endangered dead
}

\section{The billions of specimens in natural-history museums are becoming more useful for tracking Earth's shrinking biodiversity. But the collections also face grave threats.}

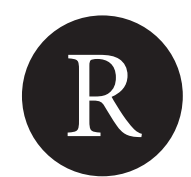

icardo Moratelli surveys several hundred dead bats - their wings neatly folded - in a room deep inside the Smithsonian Institution in Washington DC. He moves methodically among specimens arranged in ranks like a squadron of bombers on a mission. Attached to each animal's right ankle is a tag that tells Moratelli where and when the creature was collected, and by whom. Some of the tags have yellowed with age - they mark bats that were collected more than a century ago. Moratelli selects a small, compact individual with dark wings and a luxurious golden pelage. It fits easily in his cupped palm.

To the untrained eye, this specimen looks identical to the rest. But Moratelli, a postdoctoral fellow at the Smithsonian's National Museum of Natural History, has discovered that the bat in his hands is a new species. It was collected in February 1979 in an Ecuadorian forest on the western slopes of the Andes. A subadult male, it has been waiting for decades for someone such as Moratelli to recognize its uniqueness. He named it Myotis diminutus ${ }^{1}$. Before Moratelli could take that step, however, he had to collect morphometric data - precise measurements of the skull and post-cranial skeleton - from other specimens. In all, he studied 3,000 other bats from 18 collections around the world.

Myotis diminutus is not alone. And neither is Ricardo Moratelli.

Across the world, natural-history collections hold thousands of species awaiting identification. In fact, researchers today find many more novel animals and plants by sifting through decades-old specimens than they do by surveying tropical forests and remote landscapes. An estimated three-quarters of newly named mammal species are already part of a natural-history collection at the time they are identified. They sometimes sit unrecognized for a century or longer, hidden in drawers, halfforgotten in jars, misidentified, unlabelled.

"It's certainly the case that collections right now have vast resources of undescribed material," says Robert Voss, curator of mammals at the American Museum of Natural History (AMNH) in New York.

These collections are becoming increasingly valuable thanks to newly developed techniques and databases. Through DNA sequencing, digital registries and other advances, existing collections can be interrogated in new ways, revealing more about Earth's biodiversity, and how quickly it is disappearing.

But just as the collections are growing more valuable, they are falling into decline. With many institutions struggling to cope with significant budget cuts, some collections are being neglected, damaged or lost altogether. And the scientists who study them are also threatened as their positions disappear.

\section{CUTS TO COLLECTIONS}

"This is the repository of all life that we know has existed," says Michael Mares, director of the Sam Noble Museum at the University of Oklahoma in Norman, and past president of the American Society of Mammalogists. "If you want to go back and do a survey of the mammals of Kuala Lumpur or something 30 years or 40 years ago, you can't go back," he says. "You have to go to the collections to do it."

In 1758, with the publication of the encyclopaedic Systema Naturae, Carl Linnaeus attempted to classify nature - an effort that continues today at almost 8,000 natural-history collections around the world. The United States alone holds an estimated 1 billion specimens, and the global figure may reach 3 billion. The average institution displays only about $1 \%$ or less of its store. The rest - often hundreds of thousands of specimens - is catalogued and stored away, inaccessible to the public.

The collections are overseen by a dwindling corps of managers and curators - mainly taxonomists who describe species, and systematists who study the relationship between organisms. The Field Museum in Chicago, Illinois, had 39 curators in 2001. Today, there are just 21. At present, there is no curator of fishes - an enormously diverse class of animal. Neither The Field Museum nor the AMNH - which hold two of the largest collections in the world - has a lepidopterist on staff, even though both collections contain hundreds of thousands of butterfly and moth specimens. Similarly, the National Museum of Natural History has seen a steady drop in the number of curators - from a high of 122 in 1993 to a low of 81 last year.

The decline is not limited to the United States. "The situation in the United Kingdom is the same, or worse," says Paolo Viscardi, chair of the UK-based Natural Sciences Collections Association and a curator at the Horniman 
taxonomists doing it," says Wheeler. Instead, it has fallen to geneticists, behavioural zoologists and others not trained in taxonomy to name species. "Increasing numbers of biologists have to resort to naming them themselves or it simply won't get done."

Such careful taxonomic work is required for cataloguing biodiversity and protecting endangered species, says Helgen, who has named more than 30 species from specimens found in collections. "Every time I name one of these species," he says, "people start to think more about it; try to learn more about it; it gets on endangered-species lists."

Even with the problems facing museum collections and those who study them, there are some bright spots. The California Academy of Sciences in San Francisco is recruiting curators and growing its collection. This year, it will acquire a collection of 1.5 million weevils - a gift from a pair of scientists who wish to remain anonymous.

Museums are also trying to reach wider audiences by digitizing their collections and making them more accessible. "That's a major thrust to the Smithsonian right now," says John Kress, the institution's interim under-secretary for science. By the time the process is complete, he says, around 5 million botanical specimens — the oldest dating back to 1504 - will have been scanned. The California Academy of Sciences has partnered with Google to put images of its specimens online, along with other identifying information.

The push towards digitization will make collections more available for researchers as well as amateur taxonomists, who have described a growing number of species in recent years.

\section{"This is the repository of all life that we know has existed."}

But digitization cannot fill the role of physical collections, because not all databases include key data such as the three-dimensional scans of specimens that would allow researchers to remotely measure body parts.

Other technological advances, such as advanced DNA sequencing, are boosting the value of collections, allowing researchers to identify species that were previously indistinguishable from their closest relatives.

James Hanken, a herpetologist and director of the Harvard University Museum of Comparative Zoology in Cambridge, Massachusetts, has used DNA sequencing to study Thorius, a genus of pygmy salamander that is endemic to Mexico. For more than 100 years, no one was able to distinguish most Thorius species from each other. "They're very tiny animals," says Hanken. "They're hard to tell apart just by looking at them."

But DNA sequencing helped Hanken to describe and name 14 species, all of which have not been very good historically at explaining to people in nuts-and-bolts terms why it matters that we understand biodiversity."

\section{STORED VIRUSES}

Some scientists see applications for collections beyond documenting new species and studying biodiversity. The Bernice Pauahi Bishop Museum collection in Honolulu, for example, contains millions of mosquito specimens, which might tell virologists about the dynamics of mosquito-borne pathogens. Ten years ago, says Norris, researchers assumed that preservatives would have degraded the DNA of any pathogens in a specimen. But studies are showing that it is possible to recover and analyse viral DNA from museum specimens. In 2012, researchers were able to study the evolution of a retrovirus by extracting viral DNA from 120-year-old koala skins and comparing it with DNA found in skins from the $1980 \mathrm{~s}^{4}$.

Norris says that the same could be done with bats to help track diseases such as Ebola. (Researchers strongly suspect that bats triggered the recent outbreak in West Africa.) "You could go into museum collections and you could prospect for viral DNA," says Norris. The AMNH alone has more than 125,000 bat specimens from around the world. "I guarantee there is something out there that is probably more scary than Ebola that we haven't encountered yet."

But thoughts of deadly diseases are far from the mind of Moratelli as he bends to his work at the Smithsonian, calipers in hand. He carefully measures another bat, enters the data into his spreadsheet and places the animal onto a tray. Measure and repeat. In cabinets within reach, he has yet more specimens on loan from museums in Pennsylvania, Louisiana and California.

Last year, while at Texas Tech University in Lubbock, Moratelli discovered what appeared to be a specimen of an unknown species of Guyanese bat. He will know for certain later this year when he travels to Canada to compare the specimen to a large collection of several hundred bats from Guyana.

A few years ago, he travelled to the French National Museum of Natural History in Paris to inspect just two specimens. In the months ahead, Moratelli will repeat the measurement process thousands of times, and he knows he will discover new species. For some of these - critically endangered bats with dwindling habitats - his findings might help to avert extinction.

For others, it is already too late.

Christopher Kemp is a freelance writer in Grand Rapids, Michigan.

1. Moratelli, R. \& Wilson, D. E. Mamm. Biol. 76, 608-614 (2011).

2. Fontaine, B., Perrard, A. \& Bouchet, P. Curr. Biol. 22, R943-R944 (2012).

3. Helgen, K. M., Helgen, L. E. \& Wilson, D. E. Am. Mus. Novitates June, 3646 (2009).

4. Ávila-Arcos, M. C. et al. Mol. Biol. Evol. 30, 299-304 (2013). 